\title{
Chaetauchenium Tschitchérine, 1900 (Carabidae: Pterostichini) a new species and new status for a lineage from the Valdivian temperate rainforest
}

\section{Chaetauchenium Tschitchérine, 1900 (Carabidae: Pterostichini), nueva especie y nuevo estado para un linaje del bosque tropical valdiviano.}

\author{
KIPLING WILL \\ Essig Museum Of Entomology, University Of California, Berkeley, Ca, 94720, USA. \\ E-mail: Kipwill@berkeley.edu
}

\begin{abstract}
A new species Chaetauchenium loki, is described from Parque Oncol in Chile. This species, C. convexipennis (Fairmaire) and Parhypates (Antarctobium) magellanicum (Fairmaire) share a combination of features distinct from all other species attributed to Parhypates and from all other species of South American Pterostichini. To reflect this, Chaetauchenium is elevated as a distinct genus and Antarctobium is considered congeneric. Individuals of these species have highly variable and unusual patterns of supernumerary or reduced numbers of setae and variation in secondary sexual characters. Males have denticulate and falciform aedeagal parameres and females have a digitiform diverticula at the base of the spermatheca. These genital and reproductive tract features are not known from any South American pterostichine species, but are found in many Australian, New Zealand and New Caledonian species
\end{abstract}

\section{RESUMEN}

Se describe Chaetauchenium loki, una nueva especie del Parque Oncol en Chile. Esta especie, junto con C. convexipennis (Fairmaire) y Parhypates (Antarctobium) magellanicum (Fairmaire) comparte una combinación de caracteres distintos al resto de especies asignadas a Parhypates y al resto de Pterostichini sudamericanos. Atendiendo a estos caracteres morfológicos se eleva Chaetauchenium a género, que incluye además Antarctobium. Los individuos de estas especies presentan patrones altamente variables y poco frecuentes de un elevado o reducido número de sedas, y variabilidad de los caracteres sexuales secundarios. Los machos tienen parámeros del edeago denticulados y falciformes y las hembras tienen divertículos digitiformes en la base de la espermateca. Estos caracteres de la genitalia y del tracto reproductivo son desconocidos en otros pterostichinos sudamericanos, pero se hallan en muchas especies de Australia, Nueva Zelanda y Nueva Caledonia.

\section{INTRODUCTION}

The flora and fauna of southern South America and particularly organisms from temperate and cool rainforests of Chile are known for their demonstrated or presumed ancient phylogenetic relationships to taxa in other austral regions, primarily Australia and New Zealand (Winterbourna 1980; Swenson et al. 2001; Arias et al. 2008; Rix and Harvey 2010). During field work conducted in 2003-2009, which focused on sampling arthropods in the Valdivian region, a number of such taxa were found (e.g. Arias et al. 2009; Seago and Newton 2009; Slipinski and
Tomaszewska 2010). While participating in this survey effort I collected a series of large pterostichines that had the facies (Fig. 1AB) typical of New Zealand or Australian taxa, e.g. Plocamostethus or Trichosternus species, and not like most South American pterostichines. Closer study revealed that the series included two species. One I identified as Parhypates (Chaetauchenium) convexipennis, for which I have found no specimens nor records since Reed (1874) described Percus alienus, which has long been considered a synonym (Tschitschérine 1900). The second form, a similar but distinct species, was undescribed. My study of the types of Parhypates s.l. species resulted in recognizing that $P$. 
convexipennis (Fairmaire), Parhypates (Antarctobium) magellanicum (Fairmaire) and the undescribed species form a distinct group separate from all other Parhypates species and that these three comprise a distinct genus.

\section{MATERIALS AND METHODS}

Dissection methods for male and female genitalia and defensive glands, measurements and descriptive terms follow Liebherr and Will (1998) and Will (2002). Images were taken using a Microptics XLT digital imagining system and subsequently edited to enhance clarity using standard image editing software.

Material was examined from the following institutions: Essig Museum of Entomology, University of California, Berkeley, (EMEC), Colección Nacional de Insectos, Museo Nacional de Historia Natural, Santiago, Chile, Mario Elgueta, (MNNH) and, Muséum National d'Histoire Naturelle, Paris, Theirry Deuve (MNHN).

\section{RESULTS}

TAXONOMY

Chaetauchenium loki Will n.sp.

Holotype. Male, Verbatim label data: "CHILE: Reg. $\mathrm{X}$ : Province of Parque Oncol, Oncol Park, Sendero

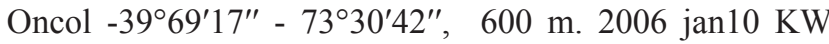
WILL, EMEC1005394", deposited MNNH, Paratypes, 1 male (EMEC1005395) and 1 female (EMEC1005396), same locality data as holotype deposited MNNH. Two females (EMEC1005397, EMEC1014244) and two males (EMEC1014243, EMEC1014242) “3941'40”S $73^{\circ} 18^{\prime} 15^{\prime}$ 'W, CHILE, Region X Oncol Park, Sendero Oncol 600m, Coll.K.Will 2008.xi.8[2]" deposited EMEC.

Etymology. The specific epithet is from the Norse mythological figure Loki, who is depicted as a shape shifter and occasional source of earthquakes. This alludes to the setal variation in this species and the Valdivian area, where this species is found, respectively.

Description. Size--. 16.1-19.8mm (sbl). Color-- Black to dark brown. Luster-- Overall rather dull, head and pronotum slightly shinier than elytra. Iridescence-- No spectral iridescence. Head--. Clypeo-ocular sulci broad, moderately impressed and divergent; mentum emarginate, sides divergent, paramedial pits shallow, broad, not deeply impressed, not well defined. Median tooth bifid, paraglossae long, free, without elongate setae at apex, ligular sclerite with two subapical setae, maxillary palpifer with one basal seta, antennae heavily-built filiform, first three segments without pubescence. Thorax--. Pronotum transverse cordiform, lateral margin sinuate in basal third, one marginal setae near the middle and one to four additional anterior setae (Fig. 2B), one seta at hind angles, basal margin slightly to deeply emarginate; pro-, meso- and metasterna glabrous, proepisternum smooth, elytral humeri rounded and narrow, elytra not bordered at base, nine striae shallowly and clearly impressed on disc, very shallow or evanescent near apex, elytral apicolateral lock not an externally evident plica, lock a large, low internal ridge, parascutellar stria absent, or present as a very short, very shallow impression, angular base of stria 1 present, parascutellar punctures present at base of stria 2, rarely unilaterally absent or with one or two additional setae (see discussion of variation below), one to four punctures in interval 3, one puncture in interval 5, rarely unilaterally absent from interval five or a single seta present in interval one (see discussion of variation below); intervals slightly convex; elytra fused, hind wing absent; anterior tarsi of male and female with three basal segments symmetrical, narrow and lacking ventral squamous setae, tarsi dorsally glabrous. Abdomen--. Ventrites 3-6 without transvers sulci; aedeagus (Fig. 3E-H) ostium dorsal, oriented left side up in repose; left paramere large, broad with large, apical denticle, right very elongate falciform, narrowly rounded at apex; female reproductive tract (Fig. 4) with dorsolateral bursal lobe, spermatheca broadly attached laterally at base of common oviduct, spermatheca with appended gland, spermatheca with duct digital diverticulum near base, without spermathecal gland duct diverticulum. Defensive gland reservoir simple, without dorsal lobe.

VARIATION OF SETAE AND SECONDARY SEXUAL CHARACTERS.

Among and within the three Chaetauchenium species there is significant variation of the primary setae. This is especially true for $C$. loki (seven specimens) and $C$. convexipennis (11 specimens). Chaetauchenium magellanicum is only known from two syntype specimens, both female. The $C$. magellanicum specimens have one supraorbital seta over each eye, except for unilaterally in one individual that has two. Otherwise their pattern of setation is fairly typical for pterostichini, i.e. one setae near hind angle and one seta medially on margin of pronotum, interval 3 of the elytra with two dorsal punctures and parascutellar punctures lacking, the presence of the latter being highly variable in pterostichines. The remaining discussion of variation regards only $C$. loki and C. convexipennis.

Supraorbital setae. All C. loki have two supra orbital setae over each eye except for one male and one female that have three setae over one eye and two over the other. However, the 
extra seta is produced from a single pore rather than being in a separate puncture. In $C$. convexipennis the number of supraorbital setae varies from three to six, often with the left and right differing in number by one or two. Most setae in addition to the typical supraorbital pair are situated posterior and medially of those over the eye.
Protarsomeres ventral vestiture. All females in both $C$. loki and $C$. convexipennis, all males of $C$. loki and two of the four males of $C$. convexipennis have slender protaromeres that are not ventrally squamous. Two males of $C$. convexipennis have some spatulate articulo setae on the ventral surface of the first three tarsomeres but the tarsi are not notably expanded.

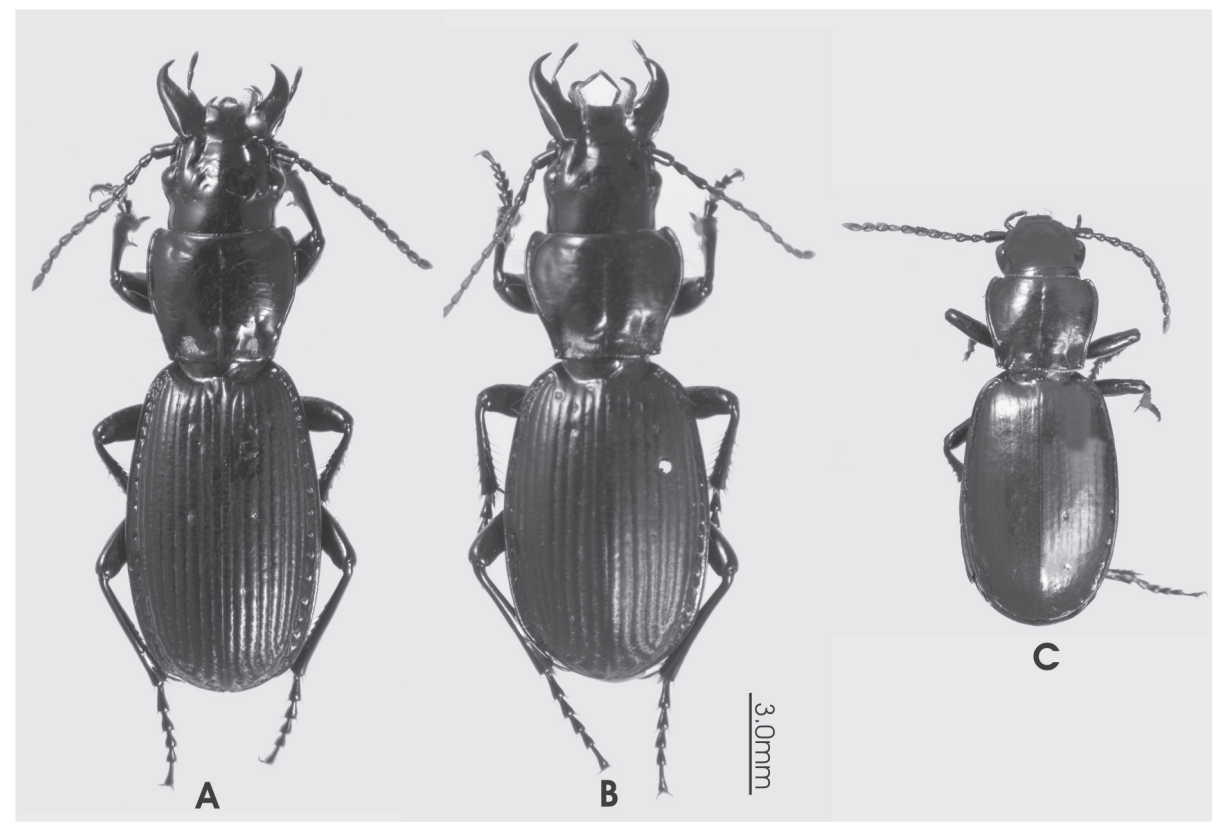

Figure 1. Dorsal habitus. A. Chaetauchenium convexipennis, B. holotype of Chaetauchenium loki and C. syntype of Chaetauchenium magallanicum.

Figura 1. Vista dorsal del hábito. A. Chaetauchenium convexipennis, B. holotipo de Chaetauchenium loki y C. sintipo de Chaetauchenium magallanicum.

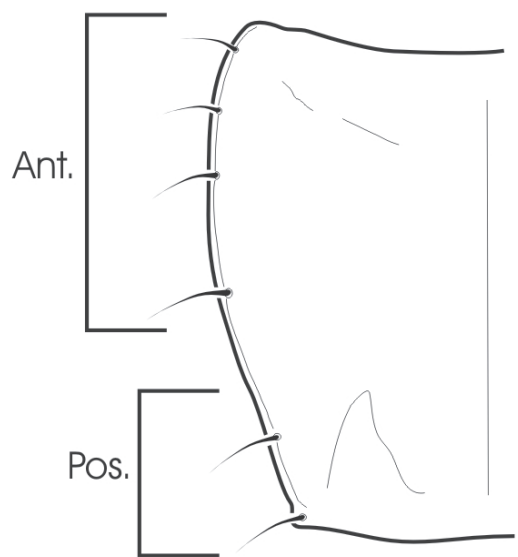

A

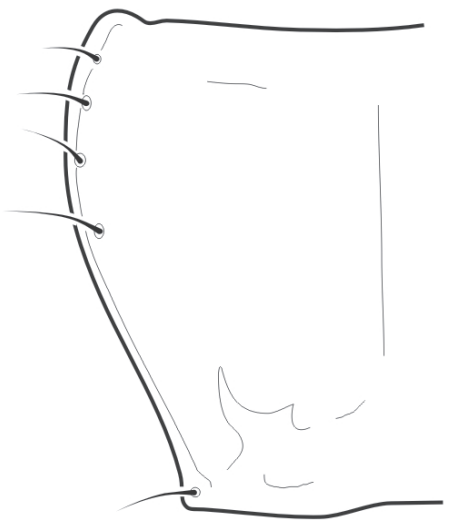

B

FIGURE 2. Pronotal lateral margin showing typical placement of setae for A. Chaetauchenium convexipennis, B. Chaetauchenium loki. Grouping indicated for discussion of variation.

Figura 2. Vista del margen lateral del pronoto mostrando la posición de las sedas de A. Chaetauchenium convexipennis, B. Chaetauchenium loki. Se indica el agrupamiento escogido para discutir la variación. 


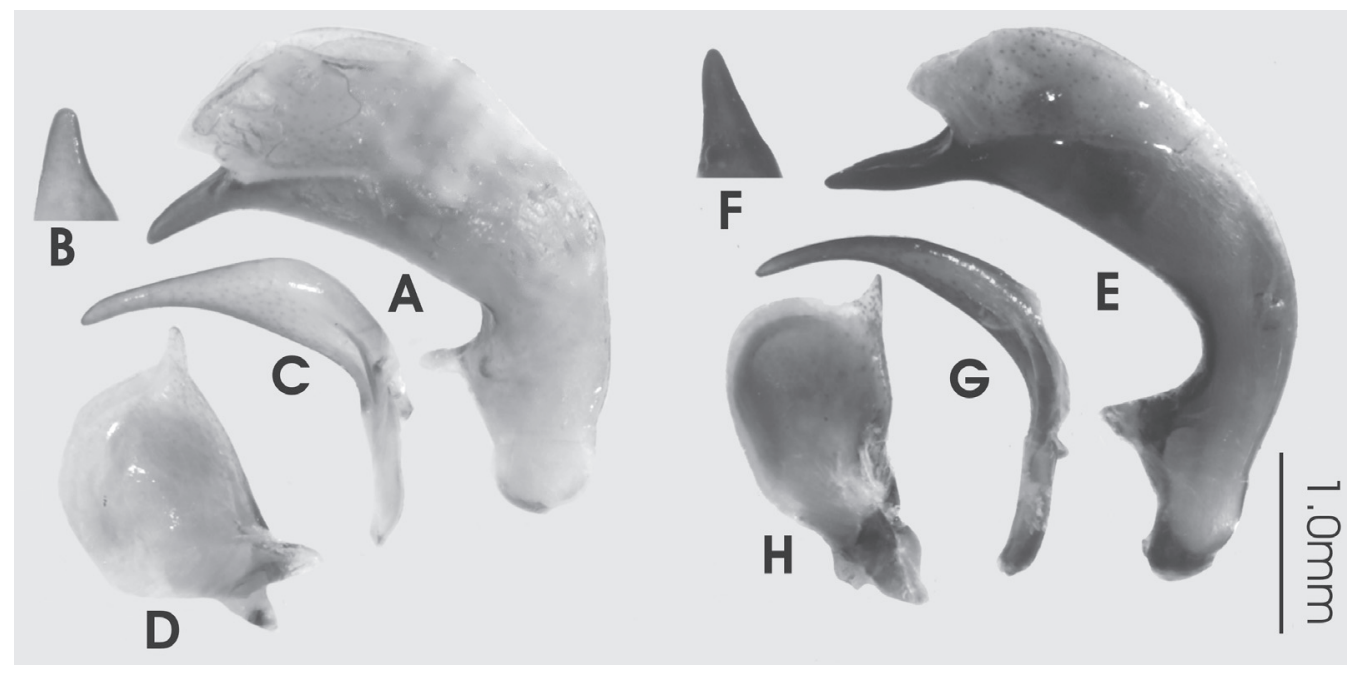

Figure 3. Aedeagus. A-D. Chaetauchenium convexipennis, E-H. Chaetauchenium loki. A, E. left lateral view of median lobe. B, F. ventral view of tip of median lobe. C, G. right paramere. D, H. left paramere.

Figura 3. Edeago. A-D. Chaetauchenium convexipennis, E-H. Chaetauchenium loki. A, E. vista lateral izquierda del lóbulo medio. B, F. vista ventral del ápice del lóbulo medio. C, G. parámero derecho. D, H. parámero izquierdo.

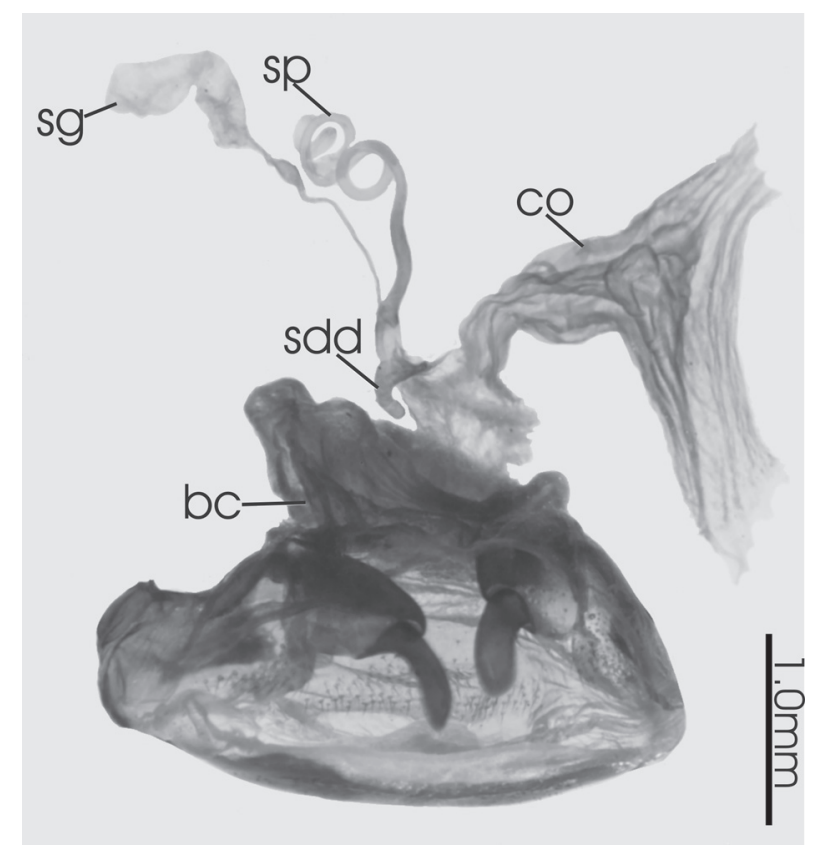

FIGURE 4. Female reproductive tract. Chaetauchenium loki. sg. spermathecal gland, sp. spermatheca, co. common oviduct, sdd. spermatheca digitiform diverticula, bc. bursa copulatrix.

Figura 4. Tracto reproductivo femenino. Chaetauchenium loki. sg. glándula de la espermateca, sp. espermateca, co. oviducto común, sdd. diverticulos digitiformes de la espermateca, bc. bolsa copuladora. 
Pronotal marginal setae. Both $C$. loki and C. convexipennis have the pronotal marginal setae with the anterior group (Fig. 2) varying from three to five setae. The sides often differ by one or two setae in a single individual. In the posterior group of setae (Fig. 2) all C. loki have one setae at the hind angle, although one individual unilaterally has an additional setae anterior to the one at the hind angle. All individuals of $C$. convexipennis have two or three setae in the posterior group.

Elytra setae. Parascutellar setigerous punctures are absent in all individuals of $C$. convexipennins. A single puncture is found on each side of the scutellum in C. loki except for two individuals that unilaterally lack the puncture and three individuals that unilaterally have two or three punctures. Punctures of interval 1 (C. loki) and interval 4 (C. convexipennis) have one individual each with a setigerous puncture. The number of punctures of interval 3 varies from one to four, with most individuals in both species having two, and occasionally and then unilaterally, three, one or four. Individuals of $C$. loki typically have one to three punctures on interval 5 except for two specimens that unilaterally lack the setigerous puntures. Chaetauchenium convexipennis has no setigerous punctures on interval 5 .

Last ventrite. Males of $C$. loki and C. convexipennis have a pair of parmedial setae on the last ventrite. Females usually have two pairs, however, in some individuals of both species, females, on one or both sides of the ventrite, have two or three setae.

\section{Key to SPeCies of ChaETAUCHENIUM}

1. Pronotum, three to five setae in the anterior group (Fig. 2), from Vadivian region. .2

1'. One seta medially on margin of pronotum, from far southern South America near Punta Arenas C. magellanicum

2. Three or more supraorbital setae, two or more setae in the posterior group on the margin of the pronotum, three to five setae in the anterior group (Fig. 2A), interval 5 without setigerous punctures and parascutellar punctures lacking

2'. Two supraorbital setae, one marginal setae near the hind angle of the pronotum (Fig 2B), one or more setae in interval 5 of the elytra and parascutellar punctures present . .C. loki

\section{DISCUSSION}

Recognition of generic status for Chaetauchenium. The combination of the denticulate and falciform aedeagal parameres (males are unknown for C. magellanicum) and female reproductive tract with a digitiform diverticula at the base of the spermatheca differentiates these three species from all other South American pterostichines. Additionally, the form of the elytral apicolateral lock, which is not an externally evident plica as in typical pterostichines, but is a low internal ridge, and the lack of the dorsal lobe of the defensive gland reservoirs, sets these species apart from Parhypates. Preliminary analysis of a combined DNA and morphologic dataset also supports monophyly of Chaetauchenium and its distant relationship to Parhypates and other South American pterostichines and suggests a closer affinity to Australian taxa (Will, unpublished data). Given these relationships, it is necessary to recognize a generic taxon to include these three species. Of the two subgenera described by Tschitschérine (1900) for these species Chaetauchenium, known from many specimens and extant populations, is selected.

\section{ACKNOWLEDGEMENT}

This study was supported by a National Science foundation grant to E. Arias and K. Will (DEB-0445413). Thanks to Carlos Ruiz for providing the Spanish translation of the abstract and figure captions.

\section{BIBLIOGRAPHY}

Arias, E.T., B.J. Richardson, \& M. Elgueta. 2008. The canopy beetle faunas of Gondwanan element trees in Chilean temperate rain forests. Journal of Biogeography, 35:914-925.

Arias, E.T., A. Slipinski, J.F. Lawrence, \& M. Elgueta. 2009. A review of the Chilean Egoliini (Coleoptera: Trogossitidae) with description of a new species of Necrobiopsis Crowson. Zootaxa, 2170: 37-45.

LiebHerR, J.K., \& K.W. WILl. 1998. Inferring phylogenetic relationships within Carabidae (Insecta, Coleoptera) from characters of the Female Reproductive Tract, pp. 107-170. In G. E. Ball, A. Casale and A. Vigna Taglianti [eds.], Phylogeny and Classification of Caraboidea (Coleoptera: Adephaga). dal Bollettino del Museo Regionale di Scienze Naturali ATTI, Torino,. 
Reed, E.C. 1874. On the Coleoptera Geodephaga of Chile. Proceedings of the Zoological Society of London, 42:48-70.

Rix, M.G., \& M.S. Harvey. 2010. The spider family Micropholcommatidae (Arachnida, Araneae, Araneoidea): a relimitation and revision at the generic level. ZooKeys, 36:1-321.

Seago, A.E., \& A.F. Newton. 2009. A new genus of Leiodid beetle from Chile, with generic key and species checklist of described Neopelatopini (Coleoptera: Leiodidae: Camiarinae). Annales Zoologici (Warsawa), 59 (3): 297-304.

Slipinski, A., \& W. TomaszewsKa. 2010. Revision of the family Cavognathidae (Coleoptera: Cucujoidea). Australian
Journal of Entomology, 49:256-267.

Swenson, U., R.S. Hill, \& S. Mcloughlin. 2001. Biogeography of Nothofagus Supports the Sequence of Gondwana Breakup. Taxon, 50:1025-1041.

Tschitschérine, T. 1900. Notes sur les Platysmatini du Museum d'Histoire Naturelle de Paris. Horae Societatis Entomologicae Rossicae, 34:448-478.

WILL, K.W. 2002. Revision of the new world abariform genera Neotalus n. gen. and Abaris Dejean (Coleoptera: Carabidae: Pterostichini (Auctorum). Annals of the Carnegie Museum of Natural History, 71:143-213.

Winterbourna, M.J. 1980. The freshwater insects of Australasia and their affinities. Palaeogeography, Palaeoclimatology, Palaeoecology, 31:235-249.

Recibido: 31.03.11

Aceptado: 27.05.11 